\title{
When two elephants fight, it is the grass that is trampled: A practical theological elucidation of the predatory attitude of hate speech
}

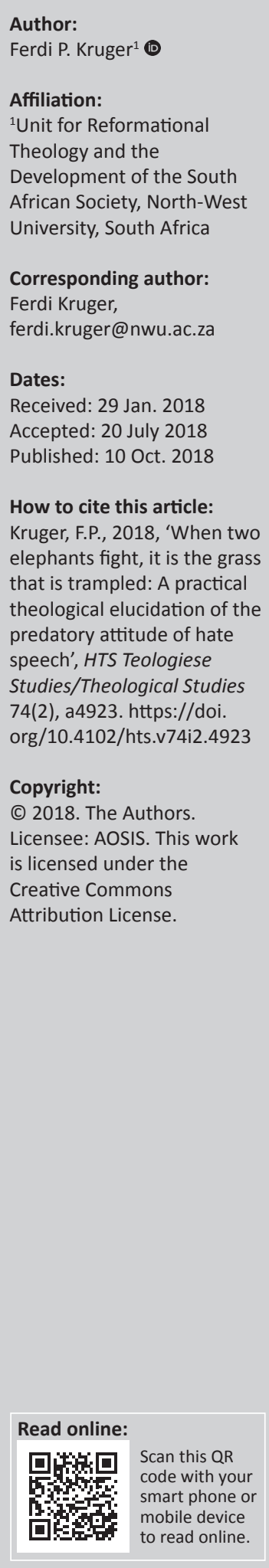

This study addresses a topic that is often neglected by faith communities, like the proverbial expression 'an elephant in the room', namely, hate speech. A community of believers could easily be guilty of practices of hate speech by keeping themselves silent or not being mindful in the way they talk about people. What is more is that the saying 'when two elephants fight, it is the grass that is trampled' represents something of the dynamics around this issue in reminding people of the harmful consequences of hate speech for people in close proximity to people who are guilty of hate speech. This article argues that a greater awareness of the intrinsic aspects involved in hate speech is needed before one could even mention the issue of combating it. The predatory attitude that underlies hate speech is examined from a practical theological vantage point. The functioning of attitudes, inner speech, attributes and silence are elucidated. The research question therefore asks whether the silence of faith communities on the predatory nature of hate speech in the public sphere contributes to the fact that people are unaware of their own attributional biases. These biases consequently gather momentum and are voiced as hate speech. This research offers analytical perspectives from the viewpoint of ethics, social psychology and communication sciences to indicate the value of speaking truth in love. Perspectives on the concept of boldness, speaking truth in love and the attitude of like-mindedness with Christ are also offered. After this hermeneutical consideration, the article concludes with practical theological perspectives on how hate speech could be addressed.

\section{Introduction}

What is the true meaning of the African proverb of the Kikuyu people, a tribal group in Kenya, saying that 'when two elephants fight, it is the grass that is trampled'? In essence, the proverb tries to explain that if there is a problem between two people or there is a problem in general (such as an us-vs. they-attitude), it does not only affect the people whose problem it is, but everyone around them also suffers as a result of their arguing (Walters 2012:18). Walters (2012:17), the author of a book that revisits the matter of hate speech, was interested in how a bigger awareness of the vulnerability of otherness in society could be created in civil society. What is said and attributed to the out-group in speech is contagious in its effects because bad examples open the possibility for followers also to label people from the out-group and to treat them in an undignified manner (Jhally 2005:4). The part of the proverb that says '.. it is the grass that is trampled' denotes that the fighting parties may get over it and recover quickly, but the affected bystanders would need time to heal, maybe even more time than it took those who started the fighting (Soni 2016:42). In this article, it will be indicated that a predatory attitude is underlying this phenomenon of hate speech. Hate speech is a speech that attacks a person or a group on the basis of attributes such as race, religion, ethnic origin, national origin, gender, disability, sexual orientation or gender identity (cf. Papanikolatos 1998:9).

Examples of hate speech from prominent individuals are of public concern. In a controversial judgement, Julius Malema was found guilty of hate speech for singing his song 'The Boers are dogs' in terms of the Promotion of Equality and Prevention of Unfair Discrimination Act (4 of 2000), also known as the Equality Act. The matter was later settled out of court after Malema appealed, and with this settlement came an opportunity to test the definition of hate speech in the Supreme Court of Appeal. The Act prohibits hate speech on the grounds of, among others, race, gender and religion. The debate about what constitutes hate speech was reignited when a Durban estate agent, Penny Sparrow, referred to black people as 'monkeys' on social media.

Note: This article is published in the section Practical Theology of the Society for Practical Theology in South Africa. 
Several potential court cases still lurk in the aftermath of that incident ${ }^{1}$. This article is not primarily concerned with what is being said or whether it constitutes hate speech or not, but rather with the underlying attitudes and their effects on society. The paradigm of the inflation on a society's sense of community is really at the core of this investigation.

The presence and mechanism of hate speech in the South African society despite the enforcement of legal prevention measures and explicit requests from authorities is an important matter because it seems like legislation does not always have the appropriate effect. Hate speech entails any kind of communication (private or public) in which people utilise selective language to legitimise negative thinking about people who are not part of the in-group, the 'us', but of the out-group, the 'them' (Papanikolatos 1998:10). Culture, gender and violence are recurring themes within the broader South African context, but it is often clutched within a dangerous intersection in people's communication about the other person or the other group.

Whatever it is, harmful speech (hate speech) occurs when someone uses language, whether spoken or written, to cause harm to a person or to a certain group on the basis of attributes such as gender, ethnic origin, religion, race, disability and sexual orientation (Cleary 2010:26; Morton 2004:3). The concept of hate speech makes reference to a speech that attacks the person or the group at whom it is directed on the basis of an attitude of hatred or incitement of harm. Hate speech can affect every single person able to communicate. A person can even be a victim of verbal abuse if he or she lives alone because of his or her inner talk, the voice in his or her head (the voice on the shoulder). No one anywhere is immune to the violence of verbal abuse. It is a threat to people's dignity (Morton 2004:3).

From the definition provided above, it seems like people notice other people's most obvious attributes ${ }^{2}$ first, namely, gender, race, age, dress and how physically attractive or unattractive they are (Bergh \& Theron 2006:44). First impressions (attributions) are important because they are so powerful in colouring the later ideas we form about people. The underlying concern from a practical theological vantage point is that communication underpins communion between people. It is one of the most basic skills at people's disposal, yet it is also one of the most worrying aspects, because communication can have such dehumanising effects. Communicative acts are above all aimed at understanding other people's viewpoints and the encounters between people (Habermas 1993:147). Habermas is clear about the fact

1.See Kruger (2017) in Du Rand et al. (2017). In Chapter 7, the author elaborates on addressing the phenomenon of the predatory nature of hate speech. It is indicated that people tend to locate the cause of behaviour either within a person (personal factors) or outside a person (environmental factors). People react quickly with a process of taxonomy when they observe other people.

2.People are making attributions because they have the need to understand their own experiences of people. It is an attempt to make sense of other people's factors should be considered: people make atributions when unusuat factors should be considered: people make attributions when unusual events grab their attention, people make attributions when events have persona consequences for them, and people make attributions when other people behave in unexpected ways (cf. Kruger 2017:207). that there are certain prerequisites before people can meaningfully understand each other, such as that they have to treat each other equally and should accept each other as independent interlocutors (Pieterse 2011:12; Vos 1995:14).

The central theoretical argument of this article is that first impressions are enduring and that the voice of hate speech divulges attributional biases that are drenched with people's own inner voice regarding attitudes towards the 'other'. The research question is whether the silence of faith communities regarding the predatory nature of hate speech within the public sphere contributes to the fact that people are unaware of their own attributional biases. As a result of ignorance, these biases derail and manifest as hate speech. The methodological insights of Dingemans (1996:62) are regarded as suitable for research on this matter. This entails that the study divides into the following three phases in a hermeneutical interaction of perspectives:

- the analytical description of the problematic praxis

- research on normative perspectives

- the development of practical theological perspectives.

\section{Analytical description of the predatory praxis of hate speech A brief description of research on the role of communication in societal issues}

In this section, two literature studies were selected and organised in order to indicate the importance of communication and the possible harm that could be caused if it is not utilised in a responsible manner. Since 2006 there has been increasing interest on the topic of the role of the church within society. This section offers a limited sample of literature on the matter of societal involvement to indicate that the interest of this article should be regarded as a focus within the broader stream of research. Louw (2017:261), for example, indicated the importance of civil displacement and hospitality in society. He further indicated that democratic societies are at a crossroads, oscillating between resistance (anxiety and hate) and outreach (maintaining human rights). This makes evident a tension field that oscillates between resistance and accommodation. Cambell and Cilliers (2012:37) focused on intrusive communication in society and indicate that the communication of the church should interrupt people in their lives. The impact of resistance on the communication process is something people should consider. Intrusive communication, though, has to inspire resistance to all powers that hold people captive. It is about changing people's perceptions and, above all, about discernment when considering societal issues (Cambell \& Cilliers 2012:38). Within a South African context, it seems like ecclesiastical resolution-making on aspects such as inter alia racism, gender, denominational differences and societal aspects is not always realising people's expectations. Landau (1981:91) indicated the danger of anthroponomy subordination as a danger where a faith community 
seemingly reflects in a theological manner but the abilities and dislikes of people stand central. The manner in which robust discussions are undertaken could even give the impression that a faith community is not always aware of the dangers of being guilty of hate speech.

Keller (2012:194) aims at the resilient power of attitudes regarding other people and is concerned about the church's view on culture that will certainly influence the type of communication that becomes evident. The author identifies five possible attitudes and possible reactions on culture:

- A withdrawal from the world into the safe space of the church: this is typical of an attitude of neglecting people.

- The quest for a generic Christ for culture: this quest is typical of an attitude of oversimplifying.

- A Christ that is superior to culture: this idea is typical of an attitude of compulsion.

- A dualistic view of Christians as citizens of both God's kingdom and the kingdom the world.

- An attempt to change culture into a culture in Christ: this attempt is typical of an attitude where people are treated as mere objects that should adhere to a recipe book.

McMickle (2006:11) reflects on whether a solution for a problematic praxis of resistant attitudes is possible and finds that the royal consciousness in the Old Testament represents the deeply entrenched negative forces - political, economic, social or religious - of Israel. This forms the status quo, and it only offers people a vision of the future that allows them to remain in power and requires the larger masses to remain marginalised in society. The work of the prophet was to combat that single-minded vision and to show that God can and will bring about a future different from that envisioned by the ruling elite. Tubbs-Tisdale (2010:3) concurs with the view of McMickle (2006) and asks searching questions regarding prophetic preaching, such as why it is that people are sometimes tempted to substitute another God for the God of justice of the Scriptures, and why people avoid speaking the truth in love regarding some of the burning issues of our day? The issue regarding (social) justice is a focal point in Tubbs-Tisdale's evaluation of societal issues.

This call for justice was also heard in other research regarding the ethical dimension that is needed within reflection on societal issues. Vorster (2011:19), for example, reasons that although it is not the task of the church to take over the responsibilities of other social spheres such as civil societies, trade unions, political parties or even the government, it should be active as a watchdog, taking care of the plight of the poor and the marginalised and being the custodian of truth, honesty, fairness and compassion. In this way the church can be deeply involved in combating evil because they are then dealing with the root causes of the problem. Involvement within societal challenges appears to be on the radar of research.

The above arguments regarding the ripple of justice should be kept in mind when defining the deeper-lying functioning of attitudes within the relationship between church and society.
When considering the obstinate hold of dehumanising powers on human life and society, it is difficult to imagine an interface for the active functioning of idolatry in the lives of contemporary humanity, and within a South African context (De Wet \& Kruger 2015:3). People are usually glad to speak about their idols or even to defend them. Legitimate goals that are pursued to give meaning to life- for instance, the preservation and expansion of one's prosperity- and the efforts to protect oneself and one's cultural identity against attack from outside can become ideological goals. The ideas that underlie idolatry seem to be very much alive today (cf. Beale 2008:17). Idolatry, therefore, occurs just as often in the Western world where there is no literal image to be seen (Tidball 2011:16).

Hate speech as a voice that is evidence of something deeper can easily become a very dangerous tool to justify self-interest (cf. De Wet \& Kruger 2015:8). Above all, workplaces, the marketplace and civil society in South Arica are complex territories. These territories consist of a mixture of good and evil motives (attitudes) and actions that should be discerned. Different understandings of the past, perceptions of the present and scenarios for the future compete with each other in public spaces (Kretzschmar 2014:2). Tubbs-Tisdale (2010:90) underlines the fact that no local church can function in complete isolation from society. Local congregations should function in a constructive manner within local communities. Herrington, Greech and Taylor (2003:30) describe this reality as 'our wired togetherness'.

\section{Inter- and intra-disciplinary perspectives}

In this section, literature is selected from scholars who reflected on truth and truthful speaking from an ethical viewpoint, scholars who are interested in interpreting silence from a communication science viewpoint, as well as scholars who are interested in people's thinking processes and the manner in which they utilise language. This article recognises the inter- and intra-disciplinary approaches of social sciences (Cartledge 2003:15; Pieterse 2001:13). In practical theology, research often focuses on communicative acts, which causes the field to overlap with other sciences that have the same focus. This section briefly engages in an inter- and intradisciplinary discourse within the fields of ethics, social psychology and communication sciences regarding the mechanisms of hate speech and the way it is sometimes tolerated by a community of believers. In this process, the discussion offers a juxtaposition of the concepts of speaking the truth in holiness, attributes, silence and inner speech to indicate that hate speech is a complicated matter that should be addressed in a comprehensive manner.

\section{Perspectives on the ethics of communication}

President Nelson Mandela once mentioned that it is never his custom to use words lightly. He further highlighted that:

if twenty-seven years in prison have done anything to people, it was to use the silence of solitude to make people understand how precious words are and how real speech in its impact is on the way people live and die. (cf. Mle \& Maclean 2011:1374) 
Vorster (2014:153) expresses the understanding of this idea and indicates that the church is above all a communicative community that is based on God's communication, which relies on effective communication between people. In their communication, the community of believers (word-users) should be an example of the profound effect that morals have (cf. also Renkert 2017:52-53). A possible ethical point of departure could be to compare speech (communication) with a diamond in that various and radiant perspectives on the topic of communication are evident. In this instance, we investigate silence as an interpretative guide to effectively speaking the truth.

Perspectives from ethics on holiness in speaking the truth: Freedom of expression is a fundamental human right. It reinforces all other human rights and allows societies to develop and progress. Renkert (2017:55) makes an interesting statement when indicating that values in society are only as good as their manifestations and everyday actualisations. Hauerwas and Vanier (2008:77) link up with this and show interest in the concepts of tenderness and gentleness in doing the ordinary things in daily life. They regard a willingness to listen as the power supply of the attitudes listed above. It is not only the perpetrators of hate speech who should revisit their own practices, but also the persons who are injured by this and in turn speak about persons injuring others. Tenderness should not be confused with concealing the truth or even an approach of apathy. Tenderness and gentleness should rather define the way people should interact with the truth.

The ability to express one's opinion and speak freely is, however, not only about one's ability to speak, it is rather about the ability to first of all listen to others and allow the views of the other to also be heard (Hauerwas \& Vanier 2008:78). This activity of listening in gentleness and tenderness takes time to establish and should be subjected to constant attention and care. Responsibility in utilising words (count and weigh) in civil society is what is needed. Kaiser (1983:222) in this instance indicates that the interpretation of the ninth commandment, for example, has often been regarded as problematic, which simply states 'You shall not give false testimony against your neighbour'.

In his delineation of Christian ethics as Kingdom ethics, Vorster (2014:102) points out that truth creates peace and good relations between people. Speaking the truth does not limit the space between people, but rather makes possible prudent relationships between people. He evaluates the manifestation of hate speech against the background of the third commandment and underlines the fact that people who impair the covenant relationship in its wider sense by acting loveless are guilty of impairing God's love. Within the context of hate speech, Vorster further continues with his emphasis on the fact that hate speech denotes behaviour that impairs God's community of love. It is like a beast with many heads or horns. Hate speech could be found in derogatory language, humour, body language, comic representations of people, cursing and in degrading narratives about people (Vorster 2014:5).
Vorster (2014:132) and Frame (2008:831) both articulate the importance of the relationship between truth and communication within a close covenant relationship. Cilliers (2000:167) in turn is concerned about the fact that words are spoken in all spheres of life without cognisance of their influence. He also pleads that people should realise that when they are communicating, their words should be uttered in responsibility so that God's Word should be recognisable in their human words. This is a mind-boggling idea, namely, to speak in order that God's Word could be recognised in human words. Tenderness and gentleness in listening to the other without condoning wrongful things, or becoming like the other, constitutes an area of growth for a society (Hauerwas \& Vanier 2008:80). Kaiser (1983:223) focuses on the meaning of the concept of truth that should be communicated and indicates that the meaning of the Hebrew word for truth is to be steady or firm (cf. Kruger 2017:208). In speaking the truth, people edify and sustain things (Kaiser 1983:222). This concept is the opposite of falsity and falsehood. The Hebrew concept of truth therefore entails more than telling the truth. It is in fact the basis for life (Kaiser 1983:224). The ninth commandment clearly forbids the ruination of people's character and lives by not telling the truth about them (Kaiser 1983:228). Hate speech should be rejected as not speaking the truth about other people. Words and human (hate) speech are deadly.

Silence from the viewpoint of communication sciences: Berg (1995:156) referred to Niebuhr's argument that although religious tolerance in society is needed, the Christian tradition is important within societal discourses. Niebuhr further highlighted that to be responsible in society is to be able, and it is required to give account to someone for something. The idea of responsibility, with the freedom and obligation it implies, has its place in the context of social relations. To be responsible is to be a self in the presence of other selves, to whom one is bound and to whom one is able to answer freely; responsibility includes stewardship or trusteeship over things that belong to the common life of the selves. The proverbial saying that 'silence is golden' is often used in circumstances where it is thought that saying nothing is preferable to speaking, because it is not the words themselves, but the intent behind them that is important. The adage of an 'elephant in the room' carries the same intent of knowing that there is a problem, but not wanting to speak about it. This article argues that silence is indeed golden because it strips away distractions and enables people to examine their own attitudes. The gold that is silence should not be regarded as mere voicelessness. In this section, recognition of the relationship between speech and silence when considering the prickly pear, that is, hate speech, should be acknowledged. It should rather be regarded as an integral part of conscious communicative activity that increases space and opportunities for understanding of otherness (Morton 2004:5; Muers 2004a:3).

Schwartz and De La Rey (2004:225) make an interesting comment by indicating that the language people (their choice of words) use is a powerful representation of their thoughts. 
Language influences people's understanding of reality and it is a powerful mechanism in reframing people's attitudes. Dauenhauer (1980:4) for this very reason highlights the intriguing manifestations of silence. He refers to silence as an intervening act as it has the function of pausing between sentences or units of thought. Intervening silence binds the parts of an utterance. The meanings of the preceding thoughts and the following thoughts are captured within this communicative moment of silence. Silence has the function of articulating or making sense of speech. This kind of silence is not only interrupting in nature but also something that opens up new possibilities for mediating acts and new patterns of communication (Muers 2004a:6). Practical theological reflection has to be functional in this process of intervening in the praxis in a room where an elephant is present. This insight correlates with the fact that people are interpreting beings. People have to learn how to utilise communication before using it with freedom. Words and language could be very harmful and this requires caution. Silences enable people to explore mediating activities within communication.

It is notable that people claim the right to say what they are thinking, and in so doing they appeal to the constitution of the country for freedom of speech. In this regard, the concept of interrupting silence is becoming relevant. When Christians confess that they are also a moral community, their deeds and words should confirm this. When words and deeds do not complement each other, an inflation process of communication emerges (Frame 2008:829). Faith communities should contribute to establishing creative and interpretive moments of silence via liturgy, for instance. This kind of silence promotes the realisation of the value of words. Silence has the potential to enrich the value of encounters between people, even people from different cultural backgrounds and beliefs (Kruger 2017:201).

Dauenhauer (1980:75) also distinguishes something that could be described as terminal silences. This kind of silence does not open up possibilities for mediating activities (cf. intervening silence), but forbids people to speak. It is a kind of silence that declares communication or interpretation on a specific subject closed. This kind of silence declares that no further act of mediation is possible (Dauenhauer 1980:76). Muers (2004a:6) ${ }^{3}$ argues that the 20th century has confronted Western languages and culture with a terminal silence because of what he describes as the brutalisation and devaluation of words. It could also be said that silence should be regarded both as intervening (interrupting) and terminal. Discernment is needed to identify the nature of each particular situation. In this bigger ellipse, intervening silence and terminal silence are the two focal points within effective communication. In order to speak about people from a different race, gender and other country, the speakers need understanding and clarity about the dignity of people.

\footnotetext{
3.See Muers (2004b): Silence happens both as something we do and as something we think about. It is a conscious communicative activity. Silence does not denote the think about. It is a conscious communicative activity. Silence does not denote the
absence of something, rather it should be regarded as something prior to speech or absence of
}

Silence to rethink one's own attributional biases and perceptions is crucial for any kind of interaction with the other. Silence as a deep-rooted method of communication is directed at people's sense of responsibility for other people's dignity. It should not function as a shield to protect people who are harming other people or as a kind of burden that makes powerless people even more powerless (Muers 2004a:9). It should not function as an excuse to turn our back on present challenges regarding race, gender, cultures and different worldviews within society. It is about an actionladen silence that creates a peephole on interpretative moments in the realisation that thinking before speaking and swallowing your words rather than contaminating people's environment should start with a hermeneutical moment of interpretive silence. Silence creates awareness of the elephant in the room. This leads to calmness and calmness leads to the utterance of therapeutic words, which makes it unpleasant for supporters of the proverbial saying 'elephant in the room'.

Perspectives from social psychology on hate speech: Within the framework of this discussion on hate speech, insights from the field of social psychology could offer valuable insights on the unworthy operation of hate speech. It provides an overview of the inner dynamics of hate speech (the elephant in the room) and deeper reasons why people are tempted to utilise hate speech to express their discomfort with the other.

Attributions play a significant role in social relations: People often choose not to speak about the elephant in the room because they find it uncomfortable to speak about it. The elephant is so big or several elephants are fighting, causing people to prefer to behave as if the elephant(s) is(are) non-existent. This article debates that when elephants are fighting, it is the grass that gets trampled. People surrounded by fighting parties get hurt. The question why people often behave as if the elephant is non-existent is intriguing. This section debates that attributes are intrinsic to what people are thinking about other people and sometimes these attributes serve as elephants in the room of people's own cognition.

Attributes are inferences that people make about the causes of events, the behaviour of others and their own behaviour (Weiten 1992:584). One can formulate it slightly differently and say that people make attributions because they have a need to understand their own experiences. It is an attempt to make sense of other people's behaviour and actions (Bergh \& Theron 2006:686; Cleary 2010:185). People react quickly with a process of taxonomy when they observe other people's actions (Louw \& Edwards 1998:424). The process of taxonomy is the evaluation in one's mind of the personal meaning of what has been observed. This process occurs organically and instantly.

The difficulty to understand the process of attribution is that it is, strictly speaking, guesswork about the causes of events and the behaviour of other people (Weiten 1992:587). Attributional errors and biases lead to inaccurate judgements 
of whether the cause of behaviour is internal or external (Barker \& Angelopulo 2010:193; Bergh \& Theron 2006:130). The harm of attributional errors is that it disturbs one's own understanding of what is happening in society. When people meet each other for the first time, they begin to form impressions of each other right away (Wood \& Wood 1999:571). This process starts early on in people's lives. People meet people from different races, genders, denominations and political convictions. The influence of opinion formers in children's lives in this regard should never be underestimated. It could be their own parents, social media, friends or events within their environment. They are listening carefully to how opinion formers speak about people who are different from themselves (the other).

Children notice obvious attributes first, namely, gender, race, age, dress and how physically attractive or unattractive someone is. First impressions (attributions) are important because they are powerful and can colour the later impressions we form about people. It is tragic, but also true, that an overall judgement of another person is influenced more by the first information received than by information that comes later (Steinberg 2011:297). Once an impression has been formed, it provides a framework based on which people interpret later information. Expectations about how other persons will act in a certain situation influence the way people act themselves. The expectations regarding gender, race, age and ethnic group also influence the perceiver's attitude, the manner in which the person treats other persons or the way he or she speaks about them. The difficulty in evaluating the attributions people make is that people use different measures to evaluate themselves (Wood \& Wood 1999:572). In brief, people have excuses for their own behaviour and thoughts, but they struggle to find excuses for other people's mistakes.

Hate speech and the acquisition of language as labelling people: When people provide something with a name, a label or a handle, they rescue it from anonymity and pluck it out of namelessness to identify it. This implies that in naming something, people are able to bring the said thing into being. The learning environment plays a major role in language acquisition (Woolfolk 2007:40). The importance of modelling parents and opinion formers can never be underestimated. Children tend to imitate the way important people in their lives speak. The way in which parents and leaders speak about race, gender and ethnic groups is something that children hear, and at some stage, they start imitating what they hear. In the meantime, faith communities that want to speak the truth according to their beliefs are being challenged in the acts of preaching their ecclesiastical resolutions on gender, race and other denominations - it includes what they are writing in newspapers and journals. It seems as if faith communities indeed have to do much rethinking and research in this regard in order to enrich a problematic praxis.

The issue at stake is therefore to what extent their thinking process and the way in which they communicate is contaminated from early on. Fiske (2004:96) highlights the ripple effect of hate speech within the context of attributions. The worrying factor in the mechanisms of hate speech is that people try to offer an explanation for why people act the way they do. They do this as adults. When people experience something negative, they tend to appraise the degree of threat and harm, which enables them to cope (Fiske 2004:449). One of the ways in which people can cope with outcomes in their lives, especially when they have a stigmatised identity, is by attributing them to the other person's prejudice. Hate speech is in essence intended to harm other people because of ideological impressions (attributes) underlying the way the speakers express themselves. Hate speech is capable of instilling or inciting hatred of, or prejudice towards, a person or group of people on specified grounds, including race, nationality and ethnicity, country of origin, ethno-religious identity, religion, sexuality, gender identity or gender.

Perspectives from social psychology on the functioning of inner speech: Hate speech is in need of a propellant, called inner speech. People talk to themselves about their own attitudes, experiences, attributes and prejudices. Hustvedt (2011:188) indicates that the little voice inside people's heads, or their inner speech, is a common everyday experience. It plays a central role in human consciousness at the interplay of language and thought. As such it can contribute to the understanding of speech representations. Murphy (1989:32) underlines the sometimes unconscious operation of inner speech and indicates that when listeners listen to messages, they do it through a communicative medium of what could be described as inner speech. Inner speech is providing people with the willingness to identify their thoughts with language. Also referred to as verbal thinking, inner speaking, covert self-talk, internal monologue and internal dialogue, inner speech plays an important role (Roskies 2015:4). The concept of inner speech could be regarded as influential, for it is defined as the way in which people communicate interpersonally (Wood \& Wood 1999:379).

The view of Vygotski in defining the role of inner speech as a process that develops over time could be regarded as pivotal in addressing the issue of language acquisition and the process of thought within the listening process (Ehrichsen 2006:14). It is often said that we are our language; however, our real language, our real identity, lies in inner speech, in that ceaseless stream and generation of meaning that constitutes the individual mind. Speech originally began as a social medium of communication and in receiving the message of communication. Later on it became internalized as inner speech that verbalises people's thoughts (Woolfolk 2007:44). During every waking moment, people carry on an intriguing process of inner dialogue. Inner speech seems to be an important part of our daily life (Bergh \& Theron 2006:81). Even though most of these inner dialogues of people stay well hidden, inner speech is far more important than most people realise. From early childhood onwards, inner speech plays a vital role in regulating how people think and behave (Murphy 1989:32). Vygotski indicates that inner 
speech is not the mere interior aspect of external speech, but rather a function in itself. Inner speech is to a large extent thinking within the atmosphere of pure meanings (Murphy 1989:34). A single word, for instance, is so saturated with sense that many words would be required to explain it in external speech (Murphy 1989:34). In everyday language people often refer to the functioning of inner speech as the voice on the shoulder of a listener. Hate speech and inner speech are connected and mutually affect each other. They could track each other to label persons in a harmful manner.

\section{Normative perspectives}

This section addresses three aspects regarding the privilege to speak: the idea of boldness, the importance of speaking the truth in love and the essence of a predatory attitude when interacting with people. In the next section, the normative aspects, perspectives from communications sciences, ethics, and the perspectives from social psychology will have hermeneutical interaction with each other. It is in accordance to Dingemans' understanding of a hermeneutical discourse with tradition.

\section{The concept of boldness $-\pi \alpha \rho \rho \eta \sigma \iota \alpha$}

The Greek concept of $\pi \alpha \rho \rho \eta \sigma 1 \alpha$ is interwoven with the idea of attitude and denotes the attitude of freedom of speech. This boldness is the opposite of shyness (Hultin 2008:82). Among the Greeks, it was regarded as the biggest gift in life because it denoted the boldness of a citizen to raise a case (Du Toit 2002:71). Herholdt (1995:128) concurs with this idea and highlights the fact that this concept was a technical term referring to the Greeks' democratic (constitutional) right to speak freely and in boldness. For the Greeks and Romans, speech was also an indicator of one's character and place in society (Hultin 2008:67). The concept even implies saying anything, but with a positive attitude towards life (cf. Du Toit's 2002:71 exposition of Heb 3:6). Freedom (boldness) of speech has fundamentally to do with attitudes. Brown (1986a:734) argues that the concept of $\pi \alpha \rho \rho \eta \sigma 1 \alpha$ should be regarded as a person's confidence to communicate. This concept is typical of the Christian's boldness in witnessing and speaking about their faith in Christ.

It is evident that this kind of $\pi \alpha \rho \rho \eta \sigma 1 \alpha$ [boldness to speak their minds] functions within a solid framework of love, almost like when someone talks to a friend (Hultin 2008:84). Christians are free to speak in society, they have the boldness to communicate with people, but it is a boldness that requires that they speak the healing words of Christ. As a communicative community of believers within the resilient praxis of hate speech, Christians should be aware of the fact that their prophetic witness and the boldness to speak therapeutic words could possibly meet resistance from people who also have a boldness (hastiness) in speaking freely and harmfully about other people. Boldness in speaking healing words is constructive, but boldness in committing hate speech is destructive and dehumanising in its essence. When Christians speak in boldness, it has to do with respect for the wholeness of life. Boldness to harm people through harmful speech is inspired by hollowness and emptiness. The manner in which boldness in speech comes to the fore exposes a person's deepest attitudes towards many things.

\section{Truth or love or truth in love? (Ephesians 4:15)}

When elephants are fighting or hurting each other through hate speech, trampled remains are left behind. The opposite of this is that meaningful communication takes into account the contours of constructive footsteps. Earlier in this article, it was debated that freedom to speak should be anchored in truth. Truth, after all, should function as the prerequisite for the freedom to speak. Ephesians 4:15 offers the foundation for a certain kind of cognition regarding speaking the truth (Floor 2007:147). Christians have to scrutinise and contemplate truth within the sphere of love. People have to learn to speak in the correct manner, also regarding societal issues. When elephants fight, they themselves could be injured, but they could also be complicit to injuring vulnerable people. This could be formulated slightly differently from a positive perspective, namely that love creates the opportunity for people to live a truthful life. Whatever people say when they speak, the people around them can never forget their acts. People's words do not have any constructive influence when they are negligent with their conduct in life or if they have no awareness of togetherness.

Love for the truth and for human beings is the fertile soil in which communication should be grown (Floor 2007:148). Love without truth is like a sponge, and truth without love is like a knife, or even like a bugle with its sharp sound. Human speech that does not grow in the soil if love becomes cold, harsh and offers self-justification for own mistakes. Truth ministers love, while love opens the way for truth to reach the hearts of other people (Floor 2007:149). Freedom of speech does not mean that people are free to say whatever they want. Freedom of speech is connected to both love and truth. Love and truth are the strong legs of constructive communication. Freedom is simultaneously to be bounded and committed to righteousness. Someone who is captured in the jail of hate speech is a prisoner of hate and harm. The proverbial fight of the elephants is, after all, no achievement. On the contrary, it is a low point. Above all of this, hate speech is the kind of speech of a prisoner who is captured in attributional biases and attitudes. Speaking in boldness, freedom and love is the essence of real freedom. Such a speech is concerned with constructiveness and the dignity of people.

\section{Understanding the concept of a predatory attitude - Philippians 2:5}

An attitude denotes the specific feeling that people harbour for someone or something that makes them react (speak) in a particular way (Barker \& Angelopulo2010:272). Firet (1978:264) regards attitude change as something that should lead to a reframing of spiritual or faith change. In order for this change to take place, people should be helped, through 
ministry, to develop a deeper vision of aspects that can initiate change. Ministry should help people to become aware of the underlying fallacies within the functioning of hate speech. Firet further distinguishes between two paramount sub-moments, namely, a moment of understanding (aha reactions) and a moment of change (do what you are saying). Kruger (2015:13) is interested in the obstinacy of the attitudes formed by selecting certain (selective) facts. People tend to select facts that confirm their own attitudes. People also tend to protect their own attitudes by rationalising facts that are in conflict with their attitudes. They tend to provide motivations for why certain harmful actions can be tolerated and a deeper understanding is missing. It is always easier to point out other people's mistakes and sins, but it is very difficult to understand the functioning of one's own attitudes.

This section pays attention to what kind of attitude is required from Christ' followers, especially in the manner they interact with other people. Botha (1991:48) indicates that this hymn about the attitude of Christ (Phlp 2:5-11) is structurally placed within the specific context of liturgy and worship because it was originally part of the liturgy of believers. Acting according to the attitude (mind) of Christ is something that should be practised during worship services in order for believers to participate to a larger extent in daily life. In Philippians 1:29, the expression $\tau$ o $\dot{\pi} \pi \dot{\varepsilon} \rho \chi \rho ı \varsigma \tau \bar{v}$ (on behalf of Christ) further underlines the importance of the liturgical functioning of this hymn. This expression, on behalf of Christ, is an indication that nobody lives for himself or herself. People should learn to be followers and not predators. This mindset or attitude is the result of a life in communion with Christ (Botha 1991:49).

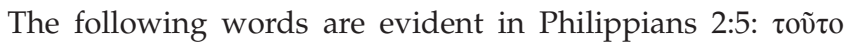

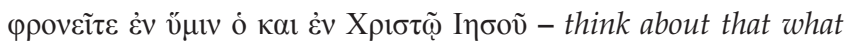
(mind) you have in Christ Jesus. The formula 'in Christ Jesus' is again important because that gives an indication that verse 5 should be understood as a directive to have the same attitude (mind) as people who are in (incorporated in) Jesus Christ (Smit 1995:182). Louw and Nida II (1993:259) indicate that the

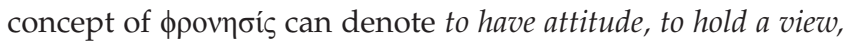
thoughtful planning or even wisdom. The concept of careful planning and wisdom in human acts offers the insight that human communication should deal with the mind of Christ that should be evident in human speech. Believers should attune their attitude to the humble mind of Jesus Christ and should take such a view of life (Manser 2010:2136). The wisdom of phronesis should therefore be the driving force behind the actions of religious communities (Louw 2015:62). Words about wisdom awake, but examples of wisdom have an effect.

Philippians 2:5-6a elaborates further on the unfolding of an attitude in Christ. The followers of Christ should have the same mindset (attitude) because they are made in God's image. Janson (2003:96-97) finds the choice to use $\mu о \rho \varphi \tilde{n}$ very interesting. This concept refers to the fact that Christ is really God. Although he is truly God, he took the form of bondservant and became a man. The concept of $\mu$ $\varphi \varphi \tilde{n}$ is used once again. Jesus fully embraced being a man. In becoming a man, he literally emptied himself. He came to serve as man and not God (Phlp 2:6). The concept of $\dot{\alpha} \rho \pi \alpha \gamma \mu$ òv as Christ's attitude is striking in this context. This concept denotes something of a predator stalking its prey. Jesus did not act like a predator (Janson 2003:99). The same mindset or attitude of Christ should be part of believers' lives. People should learn to be followers and not to become predators. When people cling to and stick only to their own voices and allow their voices to verbalise their contagious attitudes, it becomes a lifestyle of form-Christians rather than of $\mu о \rho \varphi \tilde{n}-C h r i s t i a n s$. The difference lies in the idea that Christians should not appear to look and sound like Christ, they should rather be like him and follow in his footsteps. In this instance, the harmful attitude of people is contrasted with a life style of wisdom. In this article, it was stated that people are sometimes aware of the functioning of hate speech (elephant in the room) and they are experiencing that the grass gets trampled when elephants are fighting and not the deeper attitude or mindset of people is highlighted. The harmful functioning of hate speech has a prejudicial attitude of being a predator in its core even before they are speaking in a harmful manner. It is evident that the predatory attitude will later on have an impact on the micro (victim), macro (group) and meso (society) levels of people's lives.

Louw (2015:64) therefore indicates that the concept of

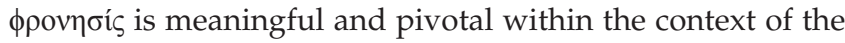
Christian faith, which deals with the issue of wisdom as the driving force behind the actions of religious communities. Wisdom is to understand the mind of Christ (to be his followers), having insight into what is right for daily life, what the driving force behind decisions is, sober judgement according to the living faith and the quest for wisdom in church and society. A person's renewed mind, which is capable of discerning God's will for societal issues, is the driving force in the evaluation of the self and of the person's real identity (Stott 1994:325).

\section{Hermeneutical interaction between the various phases of the investigation}

The following hermeneutical interaction between the various phases of the investigation emerges:

- The various ways in which a faith community utilises communication should also be aimed at interrupting people within a problematic praxis, like the functioning of hate speech within the South African society.

- The role of attitudes, and to be more specific, the predatory essence of hate speech, could not be underplayed in any kind of reflection on the manner in which people communicate with each other.

- Hate speech, attributes (first impressions), silence and inner speech substantively point at each other. People tend to provide people with a label and one way to do this is to give voice to what they are experiencing 
intrinsically. In other words, the voice of hate speech betrays attributional biases and predatory attitudes.

- No one is immune to the trend to be harmful in speech. The deeper and inner dynamics of personhood are something that cannot be denied. What is clear is that the communicative activity of silence is needed to speak truth in holiness. Silence can be hermeneutical as it aims to understand people's unique worth and dignity. The South African society is in need of interlocutors and not predators.

- Boldness to speak (their mind) always functions within a framework of love. Hate speech divulges people's deepest attitudes.

- The challenge of otherness should be regarded as an opportunity to understand the wealth of togetherness, where otherness and togetherness function in an elliptical relationship with two focal points of interest.

- Hate speech betrays the opportunity to speak the truth in love and adversely affects human dignity. Awareness of the elephant in the room does not entail tolerance of hate speech, not even in seemingly humoristic fashion. When two elephants fight, it is the grass that is trampled.

\section{A practical theological approach in addressing the functioning of hate speech}

Until now, the author reflected on the tension between a problematic praxis and theoretical insights. The following perspectives regarding a possible practical theological approach that is based on the findings of this research are now being offered.

\section{The importance of silence before naming the predatory attributes and attitudes underlying hate speech}

In addressing the phenomenon of hate speech in society, it can easily become just another way to stand in a space against the perpetrators of hate speech without realising the essence of cleaning one's own door first. This is why this article articulates the importance of silence as a process of becoming aware of one's own attributes, biases and attitudes. Without realising the deeper-lying attitudes in the functioning of hate speech, a unilateral condemnation of a practice could take place without any kind of understanding of the inner dynamics of otherness in society. Actually addressing the problem should first deal with a new lifestyle in which dignity is regarded highly, rather than as a mere replacement of hate speech with a new kind of speech that underplays. A discovery of what happens when you put yourself in the shoes of people who are different from you and who are objects of your own taxation could possibly offer a new kind of understanding.

The role of silence should be considered when reflecting on mediation, a silence that is interested in what is going on in society in a priestly manner (cf. Osmer 2008:33). It correlates with Heitink's approach to try to understand before trying to explain your point of view to people (Heitink 1999:115). According to this approach, the idea that mediation is focussed on reaching out to others in society is central (Heitink 1999:294). He describes it as the missional-diaconal presentation of the church. There is a two-way traffic where Christians listen to the people they are reaching out to and vice versa. The effect of this on meaningful communication should never be underestimated.

The liturgy of worship services could be regarded as pivotal in helping participants to see and hear the contours of the reality of life differently. One of the faith community's most important spaces for listening or becoming silent is the worship services. In this sense of the word, liturgy as an intervening act in its essence always challenges realities in life in a prophetic manner, namely, attitudes, culture, ideologies, political realities, economical injustices and aspects that influence human dignity (Smit 2008:144). God's presence in worship services urges people to become silent in a world full of noises. Liturgical participation entails a moment of discovery brought about by the interaction between listening and doing. After all, the fact that God utilises worship services to send his children back to the world in order to live in a creative and new manner is pivotal.

Earlier on in this article, the discussion touched briefly on the fact that people, also preachers, sometimes shy away from the challenge of naming evil practices boldly. They even fail completely in the area of demonstrating a liturgy of togetherness. Boesak (2015:9) indicates the watershed moment of this all and highlights that the evil in the world should indeed be named. He even elaborates by saying that the moment of naming the evil is the moment when the church as a community of believers becomes aware of God's calling that they should participate in his mission of God to abolish evils.

One of the distressing reasons is the possibility of the preacher's own attributes regarding societal issues. To speak in boldness despite one's own attributes is very demanding. Preachers and Christians who should witness sometimes experience internal resistance regarding this aspect because of their deeper and underlying attributes, perceptions and attitudes. People do not want to distance themselves from their attributes and attitudes. They do not want to be told about the wrongness of their attitudes. It is easy to recognise the beam in another person's eye, but it is difficult to recognise the splinter in one's own eye. Within the idea of silence is included a broken heart about things like hate speech, which is something that makes God sad. Therefore, silence that precedes action has to be regarded as important because it enables people to hear God's voice over the predatory voice of hate speech and to recognise the propellant of their own inner voice.

\section{Discernment as power supply for the liturgy of togetherness}

Liturgy mediates and at the same time leads to the discernment of an awareness of other people in daily life. 
Discernment in society has to do with the fact that believers have something in common with this world. A liturgy of togetherness enables people to think less of themselves (not about themselves) and more about other people. Liturgy as a bridging process has to mediate the road to the otherness of life. The bridge created by liturgy forms a very important intersection of the communicative acts between people in society. It could help people to understand the underlying attitudes in the functioning of hate speech.

Predatory language, like hate speech, is something that Christians do not want to tolerate within their immediate community. From the fullness of the heart, the mouth speaks. The community (societas) of friends is no dumping site for ravening predators while the roar of hate speech is audible. Instructing children within the space of youth ministry could offer further dynamic opportunities to address this issue of regarding other people not as 'them', but rather as friends (us). Children should be exposed to people from other cultural backgrounds and other opinions to provide them with new directives regarding the predatory speech that often emanates from first impressions. They should gain a new understanding of attributes that could lead to harmful speech. Children should learn about the fact that when elephants are fighting, it is the grass that gets trampled.

\section{Persuasive language as organic manner to address hate speech}

Persuasive communication is a communication that intentionally aims to change a person's attitudes and behaviour (Louw \& Edwards 1998:711). Within faith communities there are numerous opportunities to influence people's lives and views. The proclamation of the Word (preaching and witnessing) is regarded as suitable ways to utilise persuasive communication. Tubbs and Moss (2008:524) pay attention to the role of persuasive messages where the primary intention is not mere information, but inspiring life-change. Understanding the phenomenon of hate speech rather than a mere condemnation from a supposed moral high ground demands that the idea of interpretation in the way persuasive messages are being formulated and conveyed should receive attention. It is about a hermeneutical approach towards communication that is dealing with both the text of the Word and the context of people. Each and everyone have a concrete world in which they are thinking and living (cf. Pieterse 2001:21).

Stott (2007:68) touches on a very important matter in indicating that Christians who are touched by preaching and liturgy should also have a willingness to show the change in society. A community of believers that fails to achieve that will loses its credibility in society. In view of the radiant light of God's Word, the community of believers should experience the willingness to influence people in the workplace, in friendships and in other spaces in society to become more word-responsible. However, it must be said that in addition to the church's communication, the media's interpretation of matters often takes on greater importance than what people would think. The effect of television, and to a certain extent newspapers, lies in the repetition of the major issues in society day after day (Tubbs \&Moss 2008:27). If the media decides to emphasise an ethical issue, the public is given more information more frequently. In this way, the mass media raises the level of people's consciousness. Preachers or ministers should always remember that even their own attitudes could easily be the product of media influence. The impact of social media and the Internet on the formation of people's attitudes and attributions regarding hate speech is also a reality. People listen to sermons and participate in liturgy with intrinsic attributes, perceptions and attitudes that are foreign to the language they hear in daily life. People who listen to persuasive messages could either take the role of the fighting elephants or can take the position of the trampled grass. It stimulates what is often called cognitive dissonance (Barker \&Angelopulo 2010:89). Cognitive dissonance creates awkwardness in people's lives because of two sets of information or communication that both appeal to them. Being persuasive entails that the reality of life should be confronted and be enriched by the living proclamation of God's communication in and through his beloved Son.

\section{Conclusion}

This article indicates that hate speech is, in essence, harmful and thrives within the framework of predatory attitudes. Right at the beginning it was stated that when two elephants fight, the grass is trampled. The ripple effect of hate speech is indeed contagious for people within society because the label of 'us' and 'them' is evident. In combating the functioning of hate speech against people from other races, genders or cultural groups, Christians should first become aware of their own attitudes, attributes and the voicing of their inner speech. From a practical theological viewpoint, the importance of becoming silent to understand what is happening before condemning other people who are perpetrators of hate speech is important. In understanding one's own attitude and intrinsic processes that underlie one's conduct that utilises hate speech, the persuasive voice of the Word of God should receive attention. The proverbial saying of there is an elephant of hate speech in the room could be addressed in modelling the importance of speaking the truth to people in tenderness. After all, it is about being together in society.

\section{Acknowledgements Competing interests}

The author declares that he has no financial or personal relationships which may have inappropriately influenced him in writing this article.

\section{References}

Barker, R. \& Angelopulo, G., 2010, Integrated organisational communication, Juta, Kaapstad.

Beale, G.K., 2008, We become what we worship. A Biblical theology of idolatry, Apollos, Nottingham.

Bergh, Z. \& Theron, A., 2006, Psychology in the work context, Oxford University Press, Cape Town. 
Boesak, A., 2015, 'Contemplating Allan Boesak's fascination of preaching "truth to power"', paper presented at the Society for Practical theology in South Africa, University of the Free State, Bloemfontein, 22nd January.

Botha, D.P., 1991, 'Om te Wandel in Navolging van Jesus: Filippense 2:5-11', in C.W. Burger, B.A. Muller \& D.J. Smit (eds.), Riglyne vir prediking oor die wandel met God, pp. 47-60, Lux Verbi, Cape Town.

Brown, C., 1986a, 'Parresia', in L. Coenen, E. Beyreuther \& H. Bietenhard (eds.) The New International Dictionary of the New Testament Theology III, p. 734, Zondervan, Grand Rapids, MI.

Campbell, C.L. \& Cilliers, J.H., 2012, Preaching fools. The gospel as a rhetoric of folly, Baylor University Press, Waco, TX.

Cartledge, M.J., 2003, Practical theology: Charismatic and empirical perspectives, Paternoster, London.

Cilliers, J., 2000, Die genade van gehoorsaamheid, Lux Verbi, Wellington.

Cleary, S., 2010, The communications handbook, Juta, Landsdowne.

Dauenhauer, B., 1980, Silence: The phenomenon and its ontological significance, Indiana University Press, Bloomington, IN.

De Wet, F.W. \& Kruger, F.P., 2015, 'Shattering the idols: Confronting the obstinate hold of de-humanizing powers on post-apartheid South Africans with the living presence of the crucified and resurrected Lord', In die Skriflig 49(1), Art. \#1937, 11 pages. https://doi.org/10.4102/ids.v49i1.1937

Dingemans, G.D.J., 1996, Manieren van doen: Inleiding tot de studie van de praktische theologie, Kok, Kampen.

Du Rand, J.A., Vorster, J.M. \& Vorster, N., 2017, 'Foreword', in J.A. du Rand, J.M. Vorster \& N. Vorster (eds.). Togetherness in South Africa, pp. xxiv-xxxi, AOSIS, Cape Town. https://doi.org/10.4102/aosis.2017.tsa49.00

Du Toit, A., 2002, Romeine: Hartklop van die evangelie. Beleef God se genade, CTP Drukker, Parrow.

Ehrichsen, J.F., 2006, 'Vygotskian inner speech and the reading process', Australian Journal of Educational; and Developmental Psychology 6(1), 12-25.

Firet, J., 1978, Het agogisch moment in het pastoraal optreden, J.H. Kok, Kampen.

Fiske, S.T., 2004, Social beings: Core motives in social psychology, Wiley, Princeton, NJ.

Floor, L., 2007, Uit die skatkamer van die Koninkryk, Boekuitgewers, Pretoria.

Frame, J.M., 2008, The doctrine of Christian life, P\&R Publishing, NJ.

Habermas, J., 1993, Na metafysisch denken, Kok, Kampen.

Hauerwas, S. \& Vanier, J., 2008, Living gently in a violent world, Inter Varsity Press, Madison, WI.

Heitink, G., 1999, Practical theology, Eerdmans, Grand Rapids, MI.

Herholdt, S.J., 1995, 'Die prediking van Handelinge 5:27-32', in C.W. Burger, B.A. Muller \& D.J. Smit, (reds.), Verdere riglyne vir paas-, hemelvaart en pinksterprediking, pp. 117-130, Lux Verbi, Kaapstad.

Herrington, J., Greech, R.R. \& Taylor, T., 2003, The leader's journey. Accepting the call to personal and congregational transformation, Jossey Bass, San Francisco, CA.

Hultin, J.F., 2008, The ethics of obscene speech in early Christianity and its environment, Brill, Leiden.

Hustvedt, S., 2011, 'Three emotional stories: Reflections on memory, the imagination narrative, and the self', Neuropsychoanalysis 13(2), 187-298. https://doi.org/10. $1080 / 15294145.2011 .10773674$

Janson, M., 2003, Heerlikhede uit die Skrif. 'n Bundel van vreugde en verwondering oor die grootheid en genade die Here en sy Woord, Christelike Uitgewersmaatskappy, Vereeniging.

Jhally, S., 2005, Violence, media and the crisis in masculinity, Media Education Foundation, Northampton.

Kaiser, W.C., 1983, Toward Old Testament ethics, Zondervan, Grand Rapids, MI.

Keller, T., 2012, 'A new kind of urban preacher. Prophetic preaching', C.B. Larson (ed.), Hendrikson, Peabody, MA.

Kretzschmar, L., 2014, Entering through the narrow gate and walking the hard road: The role of Christian leaders in exposing moral evil in the South African workplace, viewed n.d., from http://www.koersjournal.org.za.10.4102/koers. V79i2.2120

Kruger, F.P., 2017, 'The predatory nature of hate speech betrays attribution bias', in J.A. Du Rand, J.M. Vorster \& N. Vorster, (eds.), Togetherness in South Africa: Religious perspectives on racism, xenophobia and economic inequality, pp. 200-228, Sun Press, Cape Town.

Kruger, F.P., 2015, 'The preacher's vulnerable attitudes in naming reality in a neglected society', Verbum et Ecclesia 36(1), Art. \#1383, 9 pages. https://doi.org/10.4102/ ve.v36i1.1383
Landau, R., 1981, “'Komm Heiliger Geist du tröster wert..”. Gestaltungen des heiligen Geistes', Evangelische Theologie 41(3), 187-211. https://doi.org/10.14315/evth1981-0302

Louw, D.J., 2015, Academic theology: Between sapientia (wisdom) and scientia (science). Theory formation in Practical Theology, University of Stellenbosch, Stellenbosch.

Louw, D.J., 2017, 'Civil displacement and the human quest for xenodochia and unqualified hospitality- on becoming a caring, compassionate community in a pastoral approach to practising faith in the public space and global arena of civi society', in M. Welker, N. Koopman \& J.M. Vorster (eds.), Church in civil society, pp. 270-311, Sun Press, Cape Town.

Louw, D. \& Edwards, D., 1998, Sielkunde. 'n Inleiding vir studente in Suider-Afrika, Heinemann Continued Education, Louisville, KY.

Louw, J.P. \& Nida, E.A., 1993, Greek English lexicon of the New Testament (I), United Bible Studies, New York.

Manser, M.H., 2010, The new Matthew Henry commentary, Zondervan, MI.

McMickle, M.A., 2006, Where have all the prophets gone? Reclaiming prophetic preaching in America, Pilgrim Press, Cleveland, $\mathrm{OH}$

Mle, T.R. \& Maclean, S., 2011, 'Ethics, integrity and good governance: the case of South Africa's local sphere of government', Journal of Public Administration 46(4), 1364-1383.

Morton, A.R., 2004, 'Duncan Forrester: A public theologian', in W.F. Storrar \& A.R. Morton (eds.), Public theology for the 21st century, pp. 25-36, T\&T Clark, New York.

Muers, R., 2004a, Keeping God's silence. Towards a theological ethics of communication, Blackwell, Victoria.

Muers, R., 2004b, Keeping God's silence, Blackwell, Oxford.

Murphy, J.M., 1989, 'Listening in a second language: Hermeneutics and inner speech', Canada Journal 6(2), 23-38. https://doi.org/10.18806/tesl.v6i2.550

Osmer, R., 2008, Practical theology: An introduction, Eerdmans, Grand Rapids, MI.

Papanikolatos, N., 1998, Hate speech in the Balkans, Rummelhardgasse, Vienna.

Pieterse, H.J.C., 2001, Prediking in 'n konteks van armoede, Unisa, Pretoria.

Pieterse, H.J.C., 2011, 'Prophetic preaching in the contemporary context of South Africa', In die Skriflig/In Luce Verbi 47(1), art. \#114, 6 pages. https://do org/10.4102/ids.v47i1.114

Renkert, T., 2017, 'Fragile values, shared convictions and group agency- civil society through the lens of inferentialism', in M. Welker, N. Koopman \& J.M. Vorster (eds.), Church in civil, pp. 33-63, Sun Press, Cape Town.

Roskies, A., 2015, Thought, language and inner speech, Dartmouth College Press, Hanover.

Schwartz, L. \& De La Rey, C., 2004, Introduction to psychology, University Press, Oxford.

Smit, A., 1995, 'Nuut gedink oor leierskap in gemeentes', in C. Burger, J. Hendriks, M. Van der Merwe \& A. Smit (red.), Gemeente en bediening. Nuut gedink oor leierskap in gemeentes. Die begeleiding van 'n christelike gemeenskap, pp. 16-36, Lux Verbi, Kaapstad.

Smit, D.J., 2008, Geloof en openbare lewe, Sun Press, Stellenbosch.

Soni, P., 2016, When elephants fight, it is the grass that gets trampled, Trinity College, Hartford, CT.

Steinberg, S., 2011, An introduction to communication studies, Juta, Cape Town.

Stott, J., 2007, The living Church. Convictions of a lifelong pastor, Inter Varsity Press, Nottingham.

Stott, R.J.W., 1994, New issues facing Christians today, Zondervan, Grand Rapids, MI. Tidball, D., 2011, Preacher keep yourself from idols, Inter-Varsity Press, Nottingham.

Tubbs, S. \& Moss, S., 2008, Human communication: Principles and contexts, McGrawHills, New York.

Tubbs-Tisdale, L., 2010, Prophetic preaching, John Knox Press, Louisville, KY.

Vorster, J.M., 2011, Managing corruption in South Africa: The ethical responsibility of the church, V\&R Printers, Pretoria.

Vorster, J.M., 2014, Christelike etiek in 'n sekulariserendesamelewing, AOSIS, Durbanville. Vos, C.J.A., 1995, Die blye tyding, RGN, Pretoria.

Walters, E., 2012, When elephants fight: The lives of children in conflict in Afghanistan, Bosnia, Sri Lanka, Sudan and Uganda, Orca Book Publishers, Toronto.

Weiten, W., 1992, Psychology: Themes and variations, Brooks \& Cole, CA.

Wood, S.E. \& Wood, E.G., 1999, The world of psychology, Allyn \& Bacon, Boston, MA Woolfolk, A., 2007, Educational psychology, Pearson, Boston, MA. 